\title{
НАУКОВЕ ОБҐРУНТУВАННЯ ОСВІТНЬО-ПРОФЕСІЙНИХ ПРОГРАМ ПІДГОТОВКИ БАКАЛАВРІВ ТА МАГІСТРІВ ГРОМАДСЬКОГО ЗДОРОВ'я
}

\author{
${ }^{1}$ Національний медичний університет імені О. О. Богомольця, м. Київ, Україна \\ ${ }^{2}$ Мукачівський державний університет, м. Мукачево, Україна
}

\begin{abstract}
Мета: обґрунтувати цілі, завдання, змістове наповнення освітньо-професійних програм підготовки бакалаврів та магістрів громадського здоров'я.

Матеріали і методи. Використано бібліографічний, інформаційно-аналітичний методи та контент-аналізу.

Результати. Медико-соціальним дослідженням встановлено недосконалість сучасної системи підготовки фрахівців для служби громадського здоров'я, її недостатню відповідність сучасним стратегіям розвитку кадрових ресурсів охорони здоров'я.

У результаті аналізу стратегічних та програмних документів глобального, регіонального та національного рівнів, положень Європейської програми ключових компетенцій фрахівців громадського здоров'я ASPHER, досвіду підготовки фрахівців громадського здоров'я в провідних університетах Європи і світу з урахуванням положень освітніх стандартів та на основі даних власних досліджень, виявлено пріоритетні напрями формування кадрових ресурсів громадського здоров'я, вимоги до теоретичної і практичної підготовки фрахівців, обґрунтовано та розроблено освітньо-професійні програми підготовки бакалаврів та магістрів громадського здоров'я.

Висновки. Освітньо-професійні програми підготовки бакалаврів та магістрів громадського здоров'я забезпечують засвоєння широкого переліку знань, набуття вмінь та компетентностей для реалізації основних оперативних фрункцій громадського здоров'я, надання відповідних послуг у рамках міждисциплінарної співпраці та міжгалузевої взаємодії.
\end{abstract}

КЛЮчОВІ СЛОВА: громадське здоров'я; кадрове забезпечення; освітні програми; освітньо-професійна підготовка; стратегічні документи; компетентності.

Досягнення високого рівня здоров'я та благополуччя населення є метою розвитку суспільства і мірилом успішності реалізації цієї цілі. Світове співтовариство визнало та закріпило вказане положення в Цілях сталого розвитку ООН на 2016-2030 рр. Документом ООН «Перетворення нашого світу: Порядок денний у сфері сталого розвитку на період до 2030 року» однією з пріоритетних цілей визначено міцне здоров'я і благополуччя, яке досягається шляхом створення відповідних умов життя, забезпеченням добробуту та дотриманням засад здорового способу життя $[16,25]$.

Зважаючи на існуючі та потенційні перешкоди на шляху досягнення здоров'я для всіх, ВООЗ окреслила пріоритетні сорери діяльності, які спрямовано на подолання викликів і загроз для популяційного здоров'я, у тому числі скорочення глобального тягаря хвороб, протидії пандеміям, епідемії неіноекційних захворювань, зменшення поширеності чинників ризику та управління ними тощо [9, 11, 14, 21, 24].

У Європейському регіоні ВООЗ розроблено низку стратегічних документів, які визначають перс- пективні політику і стратегію в контексті забезпечення усім належного рівня здоров'я. Їх положення доводять необхідність комплексного підходу до вирішення наявних проблем зі здоров'ям, потребу в запровадженні та посиленні міжсекторального співробітництва, у формуванні стійких національних систем охорони здоров'я [10, 15, 17, 20].

Досвід багатьох країн свідчить про доцільність структурної перебудови системи охорони здоров'я, пріоритетний розвиток інституцій профрілактичного спрямування, насамперед служб громадського здоров'я $[18,19]$.

Вказаний напрям потребує вирішення низки питань нормативно-правового, організаційноуправлінського, фрінансово-економічного характеру тощо. Надзвичайно важливою $є$ проблема кадрового забезпечення служби громадського здоров'я у її кількісному та якісному вимірі.

Кадрове забезпечення служби громадського здоров'я потребує глибокого осмислення з точки зору загальних вимог до формування кадрових ресурсів охорони здоров'я, викладених у Глобальній стратегії з кадрових ресурсів охорони здоров'я: трудові ресурси - 2030, документах ЄРБ 
ВО03, та з точки зору специфічних вимог до фахівців громадського здоров'я в контексті їх теоретичної підготовки та практичних умінь [12, 22, 23].

Усі вказані проблеми набувають в Україні особливої актуальності з огляду на національний ландшафт здоров'я, пріоритети державної політики та напрями розбудови вітчизняної системи громадського здоров'я. Міжнародні зобов'язання України щодо стратегічного курсу на євроінтеграцію, асоціацію 3 Європейським Союзом, імплементацію в країні основ європейської політики «Здоров'я - 2020» посилюють необхідність розвитку громадського здоров'я та створення системи його кадрового забезпечення [5-7].

Упродовж останніх років у країні проведено певну роботу з розвитку людських ресурсів системи громадського здоров'я, зокрема включено спеціальність «Громадське здоров'я» в перелік галузей знань та спеціальностей, за якими здійснюють підготовку здобувачів вищої освіти, розроблено освітні стандарти підготовки бакалаврів та магістрів громадського здоров'я, опрацьовують освітні стандарти підготовки докторів фрілософії, сформовано національний та низку регіональних центрів громадського здоров'я, розпочато підготовку кадрів на додипломному та післядипломному рівнях, внесено зміни до Національного класифрікатора України ДК 003:2010 «Класифрікатор професій» 3 включенням нових профресій «фахівець 3 довкілля та здоров'я» «фрахівець з громадського здоров'я».

Водночас залишається низка невирішених проблем, які охоплюють питання розробки мети та змісту інтегрованого тестового іспиту «Крок-2» для спеціальності 229 «Громадське здоров'я», затвердження освітнього стандарту підготовки докторів фрілософії, подальшу оцінку наявних людських, фрінансових та організаційних спроможностей у системі громадського здоров'я, удосконалення та модернізацію освітніх програм громадського здоров'я відповідно до вимог та потреб.

Зміни, що відбуваються у здоров'ї населення, їх тренди та динаміка, потребують визначення пріоритетності профрілактичних заходів, корегування програм громадського здоров'я, зростання вимог до фрахової майстерності бакалаврів та магістрів, що є підґрунтям для періодичного перегляду освітніх програм для їх подальшого вдосконалення.

Мета роботи: обґрунтувати цілі, завдання, змістове наповнення освітньо-професійних програм підготовки бакалаврів та магістрів громадського здоров'я.

Матеріали і методи. При виконанні дослідження використано бібліографрічний, соціологічний, інорормаційно-аналітичний методи.

Завданнями дослідження стали: аналіз закордонних та вітчизняних джерел наукової літера- тури за тематикою дослідження; вивчення стратегічних та програмних документів ВООЗ, ЄРБ ВОО3; аналіз освітніх програм підготовки кадрів громадського здоров'я в провідних університетах Європи і світу; вивчення нормативно-правових актів із питань охорони здоров'я України; обґрунтування освітньо-професійних програм підготовки бакалаврів та магістрів громадського здоров'я.

Базу формували дані наукової літератури, стратегії та програми, затверджені ВОО3, ЄРБ ВОО3, Європейська програма ключових компетенцій фрахівців громадського здоров'я ASPHER, документи Агентства 3 акредитації освіти в сорері громадської охорони здоров'я (АРНЕА), освітні програми підготовки фрахівців громадського здоров'я в зарубіжних університетах, нормативноправові документи, що регламентують організацію національної системи охорони здоров'я, служби громадського здоров'я, підготовки кадрів.

Узагальнення результатів виконаних завдань дослідження дозволило обґрунтувати та розробити профресійно-освітні програми підготовки бакалаврів та магістрів громадського здоров'я.

Результати дослідження та їх обговорення. Аналіз положень «Здоров'я - 2020: основи Європейської політики в підтримку дій всієї держави і суспільства в інтересах здоров'я та благополуччя» висвітлив важливість розбудови системи громадського здоров'я, що викладено в пріоритетній сорері 3 «Зміцнення орієнтованих на людину систем охорони здоров'я, потенціалу громадського здоров'я, а також готовності до надзвичайних ситуацій, епіднагляду та реагування». У ньому окреслено пріоритетні напрями розвитку системи громадського здоров'я та необхідні для цього механізми.

Конкретизацію інституційної розбудови служб громадського здоров'я представлено у Європейському плані дій зі зміцнення потенціалу і послуг громадського здоров'я, в якому серед важливих оперативних фрункцій виділено забезпечення сорери громадського здоров'я кваліфрікованими кадрами достатньої чисельності. Саме в цьому документі наголошено на потребі у підготовці різних груп фрахівців, включаючи працівників охорони здоров'я, які надають традиційні послуги громадського здоров'я; спеціалістів, які надають медичні послуги, у тому числі індивідуальні профрілактичні; фрахівців, які працюють поза сектором охорони здоров'я, але їхня діяльність впливає на формування здоров'я населення. Аналіз цього документа має надзвичайно важливе значення, оскільки розкриває весь спектр переліку фрункцій громадського здоров'я та їх змістове наповнення, що необхідно враховувати при розробці освітніх програм.

Розвиток освітнього напряму в громадському здоров'ї має узгоджуватися 3 напрямами Гло- 
бальної стратегії 3 кадрових ресурсів охорони здоров'я: трудові ресурси - 2030, яка орієнтує на підвищення ефективності, якості та впливу трудових ресурсів охорони здоров'я. Це потребує фрормування виваженої політики, збільшення інвестицій у кадровий потенціал відповідно до потреб населення та сорери охорони здоров'я; моніторингу розвитку людських ресурсів і фрормування системи підзвітності.

Аналіз засад і положень, викладених у Рамковій основі для дій «На шляху до забезпечення стійких кадрів охорони здоров'я в Європейському регіоні ВООЗ», встановив пріоритетні стратегічні орієнтири в царині кадрової політики в охороні здоров'я. Вони стосуються удосконалення освітньої сорери, формування якісної системи освіти, підвищення еоективності; поліпшення планування та інвестування; збільшення потенціалу; удосконалення моніторингу тощо.

Отже, аналіз програмних і стратегічних документів міжнародних організацій в охороні здоров'я визначив концептуальну основу обґрунтування та розробки освітньо-професійних програм підготовки бакалаврів і магістрів громадського здоров'я.

Формування змістового наповнення освітніх програм вимагало дослідження Європейської програми ключових компетенцій фрахівців громадського здоров'я ASPHER [8]. Цей документ $€$ основою для визначення контенту навчання у сорері громадського здоров'я. Його фрормування повинно виходити з розуміння необхідності володіння фрахівцем громадського здоров'я багатьма компетентностями. Вони закладаються шляхом набуття особами, які навчаються, теоретичних знань та засвоєння практичних навичок з аналізу складних, динамічних моделей здоров'я населення, встановлення визначення груп ризику; окреслення цілей та вибору цільових груп для втручань; розробки рішень, їх впровадження 3 оцінкою результатів.

Для прийняття обґрунтованих рішень фрахівець громадського здоров'я повинен розуміти та оцінювати результати досліджень стану здоров'я населення, визначати актуальність, економічну доцільність та етичну прийнятність певних втручань. Це потребує розвитку широкого кола компетентностей спостереження, аналізу, діяльності, контролю за діями, які пов'язані 3 викликами для здоров'я. При цьому компетентності з досліджень та аналізу є необхідними для виконання двох функцій громадського здоров'я, а саме епіднагляду і оцінки стану здоров'я та благополуччя населення; моніторингу та реагування на небезпеки для здоров'я та при надзвичайних ситуаціях у сорері охорони здоров'я. Компетентності 3 надання послуг забезпечують можливість реалізації трьох наступних основних оперативних фрункцій громадського здоров'я: захисту здоров'я, зміцнення здоров'я та профрілактики захворювань. А компетентності, що стосуються механізмів реалізації, $є$ необхідними для основних оперативних функцій забезпечення стратегічного керівництва в інтересах здоров'я та добробуту; забезпечення сорери громадського здоров'я компетентними кадрами; забезпечення організаційних структур і фрінансування; інфрормаційно-роз'яснювальної діяльності, комунікації та соціальної мобілізації і в інтересах здоров'я; а також для сприяння розвитку наукових досліджень у сорері охорони здоров'я для наукового обґрунтування політики та практики.

Аналіз Європейської програми ключових компетенцій фрахівців громадського здоров'я ASPHER, засвідчив, що необхідними з них є знання і вміння використовувати методи, що застосовують в громадському здоров'ї; аспекти здоров'я населення у зв'язку з соціальними, економічними та політичними детермінантами; проблеми впливу на здоров'я населення та матеріально-орізичних, радіологічних, хімічних, біологічних та пов'язаних із довкіллям детермінант; питання політики, економіки, теорії організації, керівництва та управління в охороні здоров'я; заходи зі зміцнення здоров'я, охорони здоров'я та профілактики хвороб; етичні питання. Змістову основу навчання повинні формувати положення низки наукових дисциплін, у тому числі епідеміології, біостатистики, демографії, соціології, соціальної психології, гігієни, фрілософії, етики, політології, антропології, економіки, менеджменту тощо.

Вивчення та аналіз досвіду підготовки фрахівців громадського здоров'я в провідних університетах Європи та світу викладено у попередніх публікаціях $[1-4,13]$. Вони засвідчили певні відмінності в освітніх програмах, що стосувалися чисельності навчальних дисциплін, кредитів, фрорм атестації тощо. Як найбільш наближені орієнтири обрано освітні програми підготовки фрахівців громадського здоров'я в Інституті громадського здоров'я Ягелонського університету, у Варшавському та Вроцлавському медичних університетах, в Університеті м. Дебрецена, Софійському медичному університеті, Каролінському інституті, Массачусетському університеті. Аналітичні узагальнення дозволили виявити особливості базової та спеціальної підготовки, обсяги та тривалість вивчення окремих навчальних дисциплін, змістове наповнення освітніх програм, особливості регламентації практичної підготовки, матрицю результатів навчання, перспективи працевлаштування майбутніх випускників тощо.

Зважаючи на стратегічний напрям із розбудови служби громадського здоров'я в Україні та відсутність усталеної практики підготовки кадрів у сорері громадського здоров'я, проаналізовано 
програми підготовки фрахівців медико-профрілактичного профрілю. Виявлено, що освітній процес забезпечував всебічну підготовку фахівців з питань захисту здоров'я, включаючи забезпечення безпеки навколишнього середовища, праці, харчових продуктів тощо; з питань епідеміологічного нагляду; оцінки стану здоров'я населення. Водночас для виконання основних оперативних фрункцій громадського здоров'я необхідним $€$ набагато ширший обсяг знань, навичок і компетентностей, у тому числі з питань зміцнення здоров'я і впливу на соціально-економічні детермінанти; стратегічного керівництва в інтересах здоров'я; з організаційно-управлінських питань та фінансування; з інфрормаційно-роз'яснювальної діяльності, або адвокації, комунікації та соціальної мобілізації в інтересах здоров'я тощо. Це свідчить про необхідність визначення чіткої стратегії розвитку кадрових ресурсів у громадському здоров'ї та забезпечення реалізації усіх її складових, у тому числі освітньої.

Після завершення аналітичної роботи з урахуванням рекомендацій та вимог документів міжнародного та національного рівнів, досвіду аналогічної роботи за кордоном розроблено проекти освітньо-професійних програм підготовки фрахівців громадського здоров'я.

Обґрунтування освітньо-професійних програм підготовки бакалаврів та магістрів громадського здоров'я фрормувалося на основі освітніх стандартів підготовки цих фрахівців, затверджених в Україні у 2020 р. та 2018 р. відповідно. Зміст і результати освітньої діяльності з підготовки фрахівців громадського здоров'я узгоджувалися із запропонованими у даному рамковому документі.

Освітньо-професійна програма підготовки бакалаврів громадського здоров'я передбачає чотирирічний термін навчання та очну (денну) його форму. Ії̈ реалізація має за мету формування здатності застосовувати набуті знання, уміння, навички та розуміння 3 гуманітарних, фундаментальних та профресійно-орієнтованих засвоєних дисциплін для вирішення типових завдань діяльності бакалавра громадського здоров'я на відповідній посаді. Предметною галуззю знань визначено здоров'я населення, детермінанти, що на нього впливають; організаційна, управлінська, експертна, контрольно-аналітична, проектна, науково-дослідна діяльність у сорері громадського здоров'я та промоції здоров'я. Освітня програма окреслює інтегральну та низку загальних і фрахових компетентностей, програмні результати навчання. Інтегральна компетентність полягає у здатності розв'язувати складні спеціалізовані завдання та практичні проблеми у процесі професійної діяльності або навчання у сорері громадського здоров'я, що передбачає застосування теорій та методів громадського здоров'я і харак- теризується комплексністю та невизначеністю умов.

Обов'язковими компонентами освітньо-професійної бакалаврської програми в межах загальної підготовки є 13 навчальних дисциплін, у тому числі українська мова (за професійним спрямуванням), іноземна мова (за професійним спрямуванням), латинська мова та медична термінологія, біологія та генетика, загальна та аналітична хімія, біоорганічна та біологічна хімія, медична та біологічна фрізика, анатомія людини, фрізіологія, мікробіологія, вірусологія та імунологія, медична інформатика, фрілософрія, основи соціології. Професійна підготовка бакалаврів включає 39 навчальних дисциплін, у тому числі основи біоетики, основи психології та навички комунікації, основи дидактики та педагогіки, інфрормаційні технології в охороні здоров'я, медична психологія, медична соціологія, пропедевтика медицини, кваліфікована перша допомога, фармацевтична політика та фрармакоекономіка, екологія, пропедевтика гігієни, вікова гігієна, гігієна навколишнього середовища та здоров'я, здорове харчування та безпека продуктів, профресійне здоров'я та безпека праці, біобезпека, основи біостатистики, основи епідеміології, основи соціальної та медичної політики, соціальні та екологічні детермінанти здоров'я, залежності, елементи кризового втручання, глобальне здоров'я, промоція здорового способу життя, доказова медицина, система охорони здоров'я, медичне право, право в громадському здоров'ї, основи медичного та соціального страхування, геронтологія та геріатрія, якість в охороні здоров'я, моніторинг та оцінка втручань, управління проектами, менеджмент в охороні здоров'я, економіка та фрінансування охорони здоров'я, основи маркетингу, основи санітарно-епідеміологічного нагляду.

Крім того, освітньою програмою підготовки бакалаврів зі спеціальності «Громадське здоров'я» передбачено вивчення вибіркових дисциплін 3 низки запропонованих. Освітньо-професійна підготовка першого рівня вищої освіти зі спеціальності 229 «Громадське здоров'я» передбачає диференційований поділ загальноосвітніх, профресійних та вибіркових компонент освітньої програми за роками навчання залежно від кількості кредитів ЄКТС.

У цілому обсяг освітньо-профресійної програми підготовки бакалаврів громадського здоров'я становить 240 кредитів ЄКТС. Нормативна частина програми має обсяг 180 кредитів ЄКТС (75\%), вибіркова частина - 60 кредитів ЄКТС (25\%). Формою атестації є єдиний державний кваліфікаційний іспит «Крок» та практично-орієнтований іспит.

Освітньо-професійна програма підготовки магістрів громадського здоров'я передбачає термін 
навчання один рік і 10 місяців та очну (денну) його форму. Метою освітньо-професійної програми підготовки магістрів громадського здоров'я $€$ формування здатності застосовувати набуті знання, уміння, навички та розуміння з гуманітарних, фундаментальних та професійно-орієнтованих засвоєних дисциплін для вирішення типових завдань діяльності магістра громадського здоров'я на відповідній посаді.

Інтегральна компетентність передбачає здатність вирішувати складні завдання і проблеми у галузі громадського здоров'я або у процесі навчання, що передбачає проведення досліджень та/або здійснення інновацій та характеризується невизначеністю умов і вимог. Загальні та фрахові компетентності магістрів громадського здоров'я визначені програмою, узгоджуються з вимогами освітнього стандарту.

Контент освітньо-професійної програми підготовки магістрів громадського здоров'я фрормують безпека та гігієна праці, біостатистика, громадське здоров'я, моніторинг та оцінка втручань, промоція здорового способу життя, економіка, епідеміологія, комунікація та засоби масової інформації, маркетинг медичних послуг, методологія досліджень, міжнародні проблеми здоров'я, організація і управління охороною здоров'я, основи логістики, охорона навколишнього середовища, оцінка та прогнозування потреб в галузі охорони здоров'я, педагогіка здоров'я, політика в галузі охорони здоров'я, право в системі охорони здоров'я, санітарно-епідеміологічний нагляд, управління проектами в громадському здоров'ї, медичне страхування, фрармакоекономіка, фрінансування в системі охорони здоров'я, форми медичної допомоги, гігієна харчування, інфрормаційні засоби і системи в охороні здоров'я, отримання, візуалізація та зведення даних у громадському здоров'ї, психологія здоров'я, соціологія здоров'я, управління якістю в системі охорони здоров'я. Крім того, передбачено засвоєння низки вибіркових навчальних дисциплін.

Загальноосвітні, професійні та вибіркові компоненти освітньої програми освітньо-профресійної підготовки фрахівців другого рівня вищої освіти зі спеціальності 229 «Громадське здоров'я» поділено за роками навчання залежно від кількості кредитів ЄКТС.

Загальний обсяг освітньо-професійної програми підготовки магістрів становить 120 кредитів
ЄКТС. Нормативна частина програми становить 90 кредитів ЄКТС (75\%). Обсяг вибіркової частини - 30 кредитів ЄКТС (25\%), що в повному обсязі забезпечує реалізацію пункту 15 статті 62 Закону України «Про вищу освіту».

Формою атестації майбутніх магістрів громадського здоров'я $€$ єдиний державний кваліфрікаційний іспит «Крок» та публічний захист кваліфікаційної роботи. Програмою передбачено 2 спеціалізації: «Промоція здорового способу життя та епідеміологія», а також «Управління охороною здоров'я».

\section{Висновки}

Наукове обґрунтування освітньо-професійних програм підготовки бакалаврів та магістрів громадського здоров'я здійснено на основі аналізу стратегічних та програмних документів глобального, регіонального та національного рівнів, Європейської програми ключових компетенцій фахівців громадського здоров'я ASPHER, освітніх програм підготовки фрахівців громадського здоров'я університетів Європи і світу відповідно до національних освітніх стандартів.

Освітньо-профресійні програми підготовки бакалаврів та магістрів громадського здоров'я забезпечують засвоєння широкого переліку знань, набуття вмінь та компетентностей для реалізації основних оперативних фрункцій громадського здоров'я, надання відповідних послуг у рамках міждисциплінарної співпраці та міжгалузевої взаємодії.

Впровадження в освітній процес запропонованих освітньо-професійних програм підготовки бакалаврів та магістрів громадського здоров'я сприятиме формуванню сучасних кадрових ресурсів у сфрері громадського здоров'я та успішній реалізації покладених на них фрункцій.

Перспективи подальших досліджень. Враховуючи існуючі та потенційні тенденції змін у показниках здоров'я населення та чинниках, що їх визначають, змін потреби в окремих послугах громадського здоров'я, удосконалення фрорм і методів їх здійснення, необхідним $є$ постійний перегляд освітніх програм на їх відповідність вимогам до теоретичної і практичної підготовки фрахівців громадського здоров'я, подальшої оптимізації системи їх безперервного професійного розвитку тощо.

\section{Список літератури}

1. Грузєва Т. С. Громадське здоров'я (public health) як нова спеціальність: сучасні підходи до викладання (на прикладі Дебреценського університету, Угорщина) / Т. С. Грузєва, Н. В. Гречишкіна, Л. О. Литвинова // Україна. Здоров'я нації. - 2017. - № 1. - С. 166-172.

2. Грузєва Т. С. Компетентнісний підхід до підготовки фрахівців громадського здоров'я в Ягелонському університеті / Т. С. Грузєва // Україна. Здоров'я нації. - 2017. - № 4 (45). - С. 84-90. 
3. Грузєва Т. С. Особливості підготовки фрахівців громадського здоров'я в Республіці Казахстан / Т. С. Грузєва,

Т. М. Курило // Україна. Здоров'я нації. - 2017. - № 1. - С. 160-165.

4. Концептуальні підходи до обґрунтування системи підготовки кадрів для служби громадського здоров'я в Україні. Conceptual assumptions to create a system for preparation of healthcare human resources in Ukraine / Т. С. Грузєва,

І. М. Пельо, В. А. Сміянов, Л. І. Галієнко // Wiadomości Lekarskie. - 2016. - T. LXIX, № 6. - C. 719-725.

5. Концепція розвитку системи громадського здоров'я в Україні - 2016 [Електронний ресурс]. - Режим доступу : http://moz.gov.ua/docfiles/Pro_20160309_0_dod.pdf.

6. Національна стратегія побудови нової системи охорони здоров'я в Україні на період 2015-2020 рр. - К., 2015. $41 \mathrm{c.}$

7. Про затвердження плану заходів щодо реалізації Концепції розвитку системи громадського здоров'я : Розпорядження Кабінету Міністрів України від 18.08.2017 р. № 560-р [Електронний ресурс]. - Режим доступу : http:// zakon3.rada.gov.ua/laws/show/560-2017-\%D1\%80.

8. ASPHER's European List of Core Competences for the Public Health Professional. - Denmark, 2018. - 65 p.

9. COVID19 Strategy update. Geneva: WHO, 2020. - 18 p.

10. European Action Plan for Strengthening Public Health Capacities and Services / WHO Regional Office for Europe. Copenhagen, Denmark, 2015. - 42 p.

11. Global status report on noncommunicable diseases 2014 "Attaining the nine global noncommunicable diseases targets; a shared responsibility". - Geneva: WHO, 2014. - 302 p.

12. Global strategy on human resources for health: Workforce 2030 / DRAFT 1.0 submitted to the Executive Board (138th Session)// Health workforce department World Health Organization, Geneva, Switzerland, 2016. - 38 p.

13. Gruzeva T. Educational requirements and practice of public health professionals training in the Republic of Poland as a basis for formation of educational programs in Ukraine / T. Gruzeva, T. Kurylo // Health problems in Ukraine and Poland. Lviv: Editorial House of the Lviv Regional Charity Fund "Medicine and Law", 2017. - P. 46-52.

14. Guidelines on sanitation and health. Geneva: World Health Organization; 2018. -220 p.

15. Health 2020. A European policy framework and strategy for the 21st century. - Copenhagen WHO EURO, $2011 .-190$ p. 16. Health in 2015: from MDGs, Millennium Development Goals to SDGs, Sustainable Development Goals / Geneva: World Health Organization, 2015. - 216 p.

17. Implementing a Health 2020 vision: governance for health in the 21st century. Making it happen. - Copenhagen: WHO Regional Office for Europe; 2013. - 92 p.

18. Public health in Austria. An analysis of the status of public health. - Copenhagen WHO EURO, 2011. - 370 p.

19. Rechel B. Facets of Public Health in Europe / B. Rechel, M. McKee // Copenhagen: WHO Regional Office for Europe; 2014. $-378 \mathrm{p}$.

20. Strengthened health systems save more lives. An insight into WHO's European Health Systems' Strategy. - Access mode : http://www.euro.who.int/__data/assets/pdf_file/0011/78914/healthsys_savelives.pdf.

21. The 2019 Human Development Report (HDR) "Beyond income, beyond averages, beyond today: inequalities in human development in the 21st century" [Electronic resourse]. - Access mode : https://reliefweb.int/sites/reliefweb.int/ files/resources/hdr2019.pdf.

22. The toolkit for a sustainable health workforce in the WHO European Region / WHO Regional Office for Europe. Copenhagen, 2018. - $82 \mathrm{p}$.

23. Towards a sustainable health workforce in the WHO European Region: framework for action. Copenhagen: WHO Regional Office for Europe; 2017. - Access mode : http://www.euro.who.int/_data/assets/pdf_file /0011/343946/ 67wd10e_HRH_Framework_170677.pdf.

24. Tracking universal health coverage: First global monitoring report/ Geneva: World Health Organization, 2015. - 98 p. 25. Transforming our world: the 2030 Agenda for Sustainable Development [Electrinic resource]. - Access mode : https:// sustainable development.un.org/post2015/transformingourworld.

\section{References}

1. Gruzeva, T.S., Grechishkina, N.V., \& Litvinova, L.O. (2017). Hromadske zdorovia (public health) yak nova spetsialnist: suchasni pidkhody do vykladannia (na prykladi Debretsenskoho universytetu, Uhorshchyna) [Public health as a new specialty: modern approaches to teaching (on the example of Debrecen University, Hungary)]. Ukraina. Zdorovia natsii Ukraine. The Health of the Nation, 1, 166-172 [in Ukrainian].

2. Gruzeva, T.S. (2017). Kompetentnisnyi pidkhid do pidhotovky fakhivtsiv hromadskoho zdorovia $v$ Yahelonskomu universyteti [Competence approach to the training of public health specialists at the Jagiellonian University]. Ukraina. Zdorovia natsii - Ukraine. The Health of the Nation, 4 (45), 221-226 [in Ukrainian].

3. Gruzeva, T.S., \& Kurilo, T. M. (2017). Osoblyvosti pidhotovky fakhivtsiv hromads'koho zdorov"ya v Respublitsi Kazakhstan [Peculiarities of public health specialists training in the Republic of Kazakhstan]. Ukraina. Zdorovia natsii - Ukraine. The Health of the Nation, 1, 160-165 [in Ukrainian].

4. Gruzeva, T.S., Pello, I.M., Smiyanov, V.A., \& Galienko, L.I. (2016). Kontseptualni pidkhody do obhruntuvannia systemy pidhotovky kadriv dlia sluzhby hromadskoho zdorovia v Ukraini [Conceptual assumptions to create a system for preparation of healthcare human resources in Ukraine]. Wiadomości Lekarskie, LXIX (6), 719-725 [in Ukrainian].

5. (2016). Kontseptsiia rozvytku systemy hromadskoho zdorovia v Ukraini [Concept of public health system development in Ukraine]. Retrieved from: http://moz.gov.ua/docfiles/Pro_20160309_0_dod.pdf [in Ukrainian].

6. (2015). Natsionalna stratehiia pobudovy novoi systemy okhorony zdorovia v Ukraini na period 2015-2020 rr. [National strategy for building a new health care system in Ukraine for the period 2015-2020]. Kyiv [in Ukrainian]. 
7. (2017). Rozporiadzhennia Kabinetu Ministriv Ukrainy «Pro zatverdzhennia planu zakhodiv shchodo realizatsii Kontseptsii rozvytku systemy hromadskoho zdorovia» vid 18.08.2017 r. № 560 [Order of the Cabinet of Ministers of Ukraine "On approval of the action plan for the implementation of the Concept of development of the public health system" of August 18, 2017 No. 560]. Retrieved from: http://zakon3.rada.gov.ua/laws/show/560-2017-\%D1\%80 [in Ukrainian.]

8. (2018). ASPHER's European List of Core Competences for the Public Health Professional. Denmark.

9. (2020). COVID19 Strategy update. Geneva: WHO.

10. (2015). European Action Plan for Strengthening Public Health Capacities and Services. WHO Regional Office for Europe. Copenhagen, Denmark.

11. (2014). Global status report on noncommunicable diseases 2014 "Attaining the nine global noncommunicable diseases targets; a shared responsibility". Geneva: WHO.

12. (2016). Global strategy on human resources for health: Workforce 2030. DRAFT 1.0 submitted to the Executive Board (138th Session). Health workforce department World Health Organization, Geneva, Switzerland.

13. Gruzeva, T., \& Kurylo, T. (2017). Educational requirements and practice of public health pprofessionals training in the republic of Poland as a basis for formation of educational programs in Ukraine. Health problems in Ukraine and Poland. Lviv: Editorial House of the Lviv Regional Charity Fund "Medicine and Law".

14. (2018). Guidelines on sanitation and health. Geneva: World Health Organization.

15. (2011). Health 2020. A European policy framework and strategy for the 21st century. Copenhagen WHO EURO.

16. (2015). Health in 2015: from MDGs, Millennium Development Goals to SDGs, Sustainable Development Goals. Geneva: World Health Organization.

17. (2013). Implementing a Health 2020 vision: governance for health in the 21st century. Making it happen. Copenhagen: WHO Regional Office for Europe.

18. (2011). Public health in Austria. An analysis of the status of public health. Copenhagen WHO EURO.

19. Rechel, B., \& McKee, M. (2014). Facets of Public Health in Europe. Copenhagen: WHO Regional Office for Europe.

20. Strengthened health systems save more lives. An insight into WHO's European Health Systems' Strategy. Retrieved from: http://www.euro.who.int/_data/assets/pdf_file/0011/78914/healthsys_savelives.pdf.

21. The 2019 Human Development Report (HDR) "Beyond income, beyond averages, beyond today: inequalities in human development in the 21st century". Retrieved from: https:// /sites/reliefweb.int/files/resources/hdr2019.pdf.

22. (2018). The toolkit for a sustainable health workforce in the WHO European Region. WHO Regional Office for Europe. Copenhagen.

23. (2017). Towards a sustainable health workforce in the WHO European Region: framework for action. Copenhagen: WHO Regional Office for Europe. Retrieved from: http://www.euro.who.int/_data/assets/pdf_file /0011/343946/ 67wd10e_ HRH_Framework_170677.pdf.

24. (2015). Tracking universal health coverage: First global monitoring report. Geneva: World Health Organization.

25. Transforming our world: the 2030 Agenda for Sustainable Development. Retrieved from: https://sustainabledevelopment. un.org/post2015/transformingourworld.

\section{SCIENTIFIC BASIS FOR EDUCATIONAL AND PROFESSIONAL TRAINING PROGRAMS FOR BACHELORS AND MASTERS OF PUBLIC HEALTH}

T. S. Gruzieva ${ }^{1}$, N. V. Hrechyshkina ${ }^{1}$, I. M. Pelo ${ }^{1}$, V. A. Dufynets ${ }^{2}$

${ }^{1} \mathrm{O}$. Bohomolets National Medical University, Kyiv, Ukraine

${ }^{2}$ Mukachevo State University, Mukachevo, Ukraine

Purpose: to substantiate the goals, objectives, content of educational and professional programs for training bachelors and masters of public health.

Materials and Methods. Bibliographic, information-analytical methods and content analysis were used.

Results. Medical and social research revealed the imperfection of the modern system of training specialists for public health services. Insufficient compliance of the training system with modern strategies for the development of human resources for health care has been revealed.

Analysis of strategic and programmatic documents at the global, regional and national levels, the provisions of the European Program of Key Competencies of Public Health Professionals, ASPHER, the experience of training public health professionals in leading universities in the world and Europe identified priority areas for the formation of human resources for public health, requirements for theoretical and practical training of specialists. Taking into account the provisions of educational standards and on the basis of data from our own research, educational and professional training programs for bachelors and masters of public health have been substantiated and developed.

Conclusions. Educational and professional training programs for bachelors and masters of public health ensure the assimilation of a wide range of knowledge, the acquisition of skills and competencies for the implementation of the main operational functions of public health and the provision of relevant services within the framework of interdisciplinary cooperation and intersectoral interaction.

KEY WORDS: public health; staffing; educational programs; educational and vocational training; strategic documents; competencies. 
Рукопис надійшов до редакції 05.08.2020 p.

Відомості про авторів:

Грузєва Тетяна Степанівна - доктор медичних наук, профресор, завідувач кафедри соціальної медицини та громадського здоров'я Національного медичного університету імені О. О. Богомольця; тел.: +38(050) 382-68-24. Гречишкіна Наталія Володимирівна - кандидат медичних наук, доцент, доцент кафедри соціальної медицини та громадського здоров'я Національного медичного університету імені О. О. Богомольця; тел.: +38(050) 693-23-08.

Пельо Ігор Михайлович - доктор медичних наук, професор, професор кафедри гігієни та екології № 1 Національного медичного університету імені О. О. Богомольця; тел.: +38(050) 382-68-24.

Дуфинець Василь Андрійович - доктор медичних наук, доцент Мукачівського державного університету; тел.: +38(050) 969-56-01. 